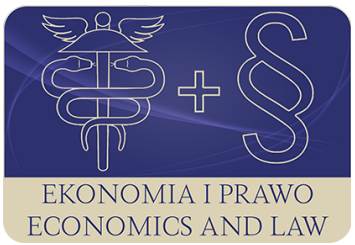

EKONOMIA I PRAWO. ECONOMICS AND LAW

Volume 16, Issue 1, March 2017

p-ISSN 1898-2255, e-ISSN 2392-1625

www.economicsandlaw.pl

EKONOMIA I PRAWO
ECONOMICS AND LAW

ORIGINAL ARTICLE

received 18.11.2015; revised 15.07.2016; accepted 31.03.2017

Citation: Łakomy-Zinowik, M. (2017). Public-private partnership as an alternative source of financing of public tasks. Ekonomia i Prawo. Ecomomics and Law, 16(1): 75-86.

doi:10.12775/EiP.2017.006.

\title{
Public-private partnership as an alternative source of financing of public tasks
}

\author{
MARTA ŁAKOMY-ZINOWIK \\ University of Szczecin, Faculty of Economics and Management, Department of Microeconomics, \\ ul. Mickiewicza 64, 71-101 Szczecin, Poland \\ $\square$ marta.lakomy@wneiz.pl
}

\begin{abstract}
Aim: The paper touches upon the issue of public-private partnership (PPP) as an alternative form of realising public tasks by the local authorities (Polish short: JST) in Poland. Motivation: Since 2009, the cooperation between the public and private sector has been used to an increasingly large extent in various areas of economy. The first part of the paper presents the legislation concerning the public-private partnership in Poland for the years 2009-2014 that regulates, defines and details the cooperation between both sectors. In order to present the scale of using the private-public partnership framework by local authorities in Poland, the last part of the text analyses reports originating from the Ministry of Economy, Polish Agency for Enterprise Development and the Public-Private Partnership Institute concerning the public-private partnership industry and concessions in Poland for the years 2009-2014.

Results: Analysis of data and its interpretation were used in order to set out the perspectives for the development of the private-public partnership industry in Poland for future

years. The statutory obligation to realise local authorities' own tasks, combined with the limited amount of budget resources, forces the local authorities to look for alternative solutions. In the light of the analyses presented here, the public-private partnership framework may become a solution for the scarcity of financial resources for many communes, poviates and regions in Poland.
\end{abstract}

Keywords: public-private partnership; own tasks of local authorities; legal regulations concerning public-private partnership

JEL: K23; E66; H40; H68 


\section{Introduction}

Starting from the systemic transformations that took place in Poland, up to the present, a three-level system of territorial division has been shaped. While in the pre-accession period all kinds of infrastructure projects were financed from the budgets of local authorities and from state subventions, after joining the European Union, local authorities started to use community found to a large extent. For ten years, local authorities of various levels construct, have been modernising and developing road, tourism, healthcare or educational infrastructure, following the idea of reaching the level of the members of the socalled 'old EU'. Depending on the project, the participation of community funds in their realisation is between a few and even $100 \%$. However, such form of financing forces local authorities to take up bank loans. An alternative form of realising public duties by local authorities may be using the framework of public-private partnership, used to an increasing degree since their formal legal implementation in Polish legal system in 2009.

The purpose of this article is to verify the hypothesis that the cooperation between public and private entities is an effective tool for realising public duties in the circumstances of increasing debt and scarcity of budget resources assigned for local authorities.

\section{The current state of knowledge}

According to Michael Geddes (2005, pp. 1-7), private-public partnership is a risk sharing relationship based upon a shared aspiration between the public sector and one or more partners from the private sector, involving the sharing of risks and rewards to deliver a publicly agreed outcome and/or public service.

Because of general usage of public-private partnership in the world, there are many foreign-language publications regarding the knowledge, both of formal and legal, and practical aspects of this form of cooperation between both sectors. The source of our knowledge about the public-private partnership projects and market in Europe are different types of platforms, such as the European PPP Expertise Centre (EPEC). It collects the data from the countries with a functioning PPP market, being a trustworthy sources of statistics and comparative analyses. Despite of the fact that public-private partnership has been used in local government's practice for less than six years, there are databases and publications concerning the PPP market in our country. The main platform of knowledge about that issue is 'The database of Public-Private Partnership projects', which was created as a form of realising the statutory duty of the Minister of Economy, consisting of promoting and, above all, monitoring the PPP market in Poland. The database gathers and provides for viewing the following data: information, analyses, publications and statistics regarding the on-going, completed and planned undertakings within the framework of public-private 
partnership. Moreover, alongside analyses and other scientific publications worth mentioning is also Bulletin of public-private partnership, issued in electronic form by the Polish Agency for Entrepreneurial Development (PARP), controlled by the ministry of economy. There are also social institutions that promote the knowledge about the public-private partnership, such as: Institute for Public-Private Partnership foundation. Taking into account the dynamism of economic changes in the world and in Poland, it is necessary to constantly monitor the PPP market and analyse its usefulness within the current market conditions.

\section{The methodology of research}

This publication was divided into two parts: theoretical and practical. The first of them was developed on the basis of analysing the publications related to the issue in question, legal acts regulating the PPP market in Poland and information collected from governmental databases regarding the public-private partnership.

The practical part related to concrete examples of realising projects within the PPP framework, analyses the results of the research done by the European Centre for PPP Expertise (EPEC), the Ministry of Economy, contained in the PPP Project Database and PPP Market Report and Bulletin for Public-Private Partnership (PARP).

\section{The research process}

In the moment of joining the European Union, the cooperation between private and public entities practiced in Western Europe in order to realise public investments, was implemented in the Polish reality. Now, in Polish law the legal framework for the Public-Private Partnership is outlined by two legal acts: Act on public-private partnership (2008) and Act on concession for public works or services (2009).

\subsection{Legal provisions concerning the PPP in Poland}

Under Polish law, public-private partnership may be defined only as the cooperation between the public and the private sector realising projects under applicable statutes. In accordance with the provisions of the Act on Public-Private Partnership (2008, art. 1.2 and 7.1): 'The object of public-private partnership is joint realisation of an undertaking based upon the distribution of duties and risks between a public and a private entity' (chapter 1, Article. 1.2), and 'Under an agreement on public-private partnership, the private entity undertakes to realise an undertaking for consideration and to bear the whole or a part of the costs for its realisation our undertakes that such costs will be borne by a third party, and the public entity undertakes to cooperate in order to reach the objective 
of the undertakings, in particular by making its own contribution' (Chapter 3 , Article 7.1). The provision stipulates that the realisation of an undertaking within the PPP framework is based upon the distribution of duties and risks between the public and the private entity.

The term 'undertaking' is directly correlated with another term used in the act of 2005 , i.e. the 'public duty'. In order to explain what a public duty is, one has to refer to the provisions of other acts. The first of such provisions is used in the Act on municipal or urban engineering (1996, art. 1 sec. 2), where Article 1 sec. 2, reads as follows: 'Municipal or urban engineering includes in particular public duties whose aim is constant and uninterrupted satisfaction of public needs by means of providing generally available services'. On the other hand, 'public needs' are included in the Act on local government (1990, art. 7 sec. 1.) as part of the duties of local government.

The choice of the entity realising the tasks of the local government may take place in two ways. The first is complying with the provisions of the Act Public procurement (2004)The second of those ways is to comply with the Act on concessions for works or services (2009). The choice of a particular statute is dependent upon the type of compensation for the private entity (Antoniuk, 2009, p. 103).

The provisions of law indicated above that regulate the principles of realising the duties of local authorities in the form of public-private cooperation aim at an effective implementation of this formula in Poland. As indicated by the statistics, from the moment of implementing the Act of 2008, the number of agreement concluded within the PPP framework has been increasing steadily. Since 2009 , until the end of 2014 a total number of 90 agreement on public-private partnership were signed out of 286 projects that were announced (Herbst et al., 2015, p. 12).

\subsection{Means of financing infrastructure projects by local governments}

Polish local governments started to gain profits from Poland's membership in the EU quite quickly. According to the data provided by the Ministry of Infrastructure and Development, in the period between the commencement of EU grant programmes until 8 November 2015, 302.2 thousand applications were filed (correct formally) for grants amounting to a total of 614.7 bln PLN (both EU and local funds). In spite of initial difficulties, local authorities have started to use European funds more frequently and more willingly. Year after year, they have been increasing their knowledge about grants, increasing their share in own budgets. Infrastructure projects created within the first years of Poland's membership in the European Union were only signalling a problem that now makes it impossible to continue with the positive trend for many, particularly poorer countries. Its core is the very process of getting grants and realising projects with European funds (Portal Funduszy Europejskich, 2015). 
The process of investment based on a European grant is based upon several key steps. The first of such requirements is making a formally correct application. If the application is deemed as positive, then a financing agreement is signed. It gives a green light for the realisation of the investment. At this stage, local governments are forced to take up a loan, as the grant covering the agreed part of the costs is credited only after the agreement was performed. After the completion of the investment, local government files an application for payment and then there is a control of the realised project. Then, unless any post-control objections are filed, the local government gets the grants guaranteed under the agreement. In the process outlined above, we can point out to one fundamental principle for absorbing European funds. It turns out that the possibilities of financing investment projects of local governments are dependent upon its credit standing (European Commission, 2004, pp. 5-6).

According to a report published by the Supreme Audit Commission, as of the end of 2014, the liabilities of local government in Poland amounted to a total of 72109.9 mln PLN and were higher than those at the end of the previous year by 4.3\% (69159.1 mln PLN). What is more some of the local governments controlled by a Regional Chamber of Audit were taking up loans in parabankinginstitutions as a result of losing liquidity and impossibility of getting a bank loan (NIK, 2015, p. 13, 22). An analysis of the influence of the European funds absorbing procedure on the level of indebtedness of some local governments indicates a necessity of searching for alternative forms of realising public duties. A new solution should both protect the local government against generating excessive budget deficit and allow for infrastructure development when a solution has already been generated.

\subsection{Benefits and risks}

The PPP formula, as a special form of realising e.g. infrastructure projects, has become the object of particular interest for the European Commission. The Guidelines regarding good public-private partnership clearly indicate that the inter-sector cooperation used with increasing frequency, results in an increase of the quality and of the effectiveness of public services in the situation when the state financial resources are limited (European Commission, 2003, pp. 4-5).

Many years of experience in using the cooperation between the public and the private sector in realising the duties of local governments in Poland and worldwide, allows to point out to a number of benefits that may be derived from such cooperation. An example of an answer for a difficult situation of local governments is a partnership model referred to as BOT (i.e. Build-Operate-Transfer) (Yescombe, 2008, p. 32). It is a form of financing where a private investor gets a concession for constructing and exploiting an element of a public construction. After the construction has been erected, the private entity gains profits from exploiting it. The BOT model is satisfying the needs of both co- 
operating partners: a private entity in the form of profits and a local government in the form of a realised duty and costless acquisition of an infrastructure element that, due to the limited amount of budget resources, would probable not have been erected (Public-Private Partnership in Infrastructure Resource Center, 2015).

The second of the benefits of the public-private partnership agreements is significant for an optimal realisation of the duties entrusted by the local government. Despite having introduced a non-price criterion in public procurement in 2014, the local governments, when choosing a contractor, most often look at the criterion that seems safest for them - i.e. the criterion of lowest price. Also, the realisation of a public-private project relies on the quality criterion. This is motivated by contractor's care over the created infrastructure, as the contractor bears full maintenance costs, including repairs and resulting difficulties in correct realisation of the task entrusted by the local government. The desire to minimise that type of risk results in an increase of the quality of public services. In addition, with the expiry of the period for granting a concession, other entities that took part in the competition, must compete with each other, which has a direct result of keeping a high quality of the provided services (Act, 2014; European Commission, 2003, p. 16).

One may not analyse the issue of public-private partnership without pointing out to the risk related to the use of public-private partnership by local governments. Since local governments are supposed to render public services with particular care for the interests of local communities, it is crucial to precisely determine in the public-private partnership who actually controls the quality and the price of the duties realised under the contract. It is extremely important from the point of view of the public sector to identify and manage the risk associated with the investment. The agreement should secure the proper implementation of the project in the public-private cooperation, and also precisely define the division of risks. The private partner before attempting the procedure may establish a special purpose company, which, thanks to its resources will ensure the proper implementation of the project. From the point of view of the public sector, important activity could be the establishment of appropriate faculty to control the investment. It is the local government that is responsible to protect the public interest by giving details of the requirements for the private contractor and the supervision over its realisation. In the situation of improper realisation of the controlling function by a local government, realisation of the public duties becomes pathological, harming the local community (European Commission, 2003, p. 16).

Crucial thing is also to stipulate concession fees in the concession agreements. Such fees are to be paid by the users of the facilities managed by a private entity and to stipulate all rules of modifying such fees. The amount of stipulated fees should secure the interest of the beneficiaries, and to encourage the private entity to maintain a proper quality of the rendered services. Too weak financial 
motivation may result in reduction of expenditures by the contractor-concession holder.

Another risk factor that may result in a decreasing quality of rendered services is also the lack of competition. While introducing competition to the public sector is a big advantage of the public-private partnership indicated by the European Commission, monopoly may lead to pathologies is realising the duties of the local government. Low competition or the lack thereof does not force the private entity to maintain a high quality of the services rendered, as there is no real alternative for the contractor. Using the PPP framework when there is no competition is pointless taking into account the assumptions and practice of realising a public-private partnership project. Basing upon the experience gained so far, we can claim that despite the risks inherent in improper drafting of the PPP agreements, public-private partnership is an effective form of relieving indebted local government and to avoid stagnation in their development (European Commission, 2003, p. 4, 63).

\section{The results of research}

Since the implementation of the Act of 2008 that regulates the functioning of the PPP market in Poland, we can observe a growing tendency in using public-private partnership by local governments year after year. In total, 341 announcements were published that resulted in 90 concluded agreements. This means that only one in four (26\%) announcements in our country has led to entering into public-private partnership agreement. While in the Regions: Pomorskie, Śląskie and Wielkopolskie the effectiveness of the realisation of PPP agreements ranges above 40\%, in the Regions: Eódzkie and Podlaskie, no agreement of this type was signed (Herbst et al., 2015, p. 12) (chart 1).

Analysing which of the public entities open projects within the PPP formula, in the majority of cases it was used by local governments at different levels. They opened a total of 255 proceedings, i.e. $74 \%$ of all initiated proceedings in the period between 2009 and 2014. Among all local governments, the majority of the projects were opened by urban communes, followed by rural communes, rural-urban communes, municipalities, county governor offices, regional governor offices and district offices. The remaining entities using public-private partnership as a tool for realising own duties were: budget units, municipal companies, independent public health care units, higher education units, governmental administration, foundations, district offices and others. These were the remaining 26\% of all supplied projects (Partnerstwo Publiczno-Prywatne, 2015, p. 14) (chart 2 and 3).

According to the data contained in the PPP Market Report, the sectors where the public entity most often used the public-private partnership between 2009 and 2014, the majority (25\%) of the announcements were scheduled for realisation within the sectors of sport and recreation. They were followed by energetics $13 \%$, others $9 \%$, car parks $9 \%$, culture and education $8 \%$, healthcare $7 \%$, water 
supply and sewage disposal $6 \%$, IT 5\%, municipal facilities 5\%, transportation $4 \%$, waste disposal $4 \%$ revitalisation $3 \%$. Analysing the tendency of sector domination at the PPP market, one can note that the percentage of the projects within the area of sports and recreation is decreasing, replaced by the sector of energy. The remaining areas of public services do not show a clearly defined tendency. A boom in the energy sector consisting of implementation of public-private partnership is related to the undertakings in the area of energy effectiveness, realised within an attractive ESCO (Energy Saving Company) framework (Herbst et al., 2015, p. 15; Project Finance Poland, 2015).

The analysis of the value of public-private partnership agreements concluded in the period between 2009 and 2014 indicates that an average value of a single project is $30 \mathrm{mln}$ PLN. The most valuable were the projects in the sector of waste disposal (229 mln PLN) followed by IT projects (143 mln PLN). The value of the PPP market in particular sectors is presented in the chart 4 (Herbst et al., 2015, p. 18).

\section{Conclusion}

The analysis of data concerning the PPP market in Poland indicates that since the implementation of the new provisions of 2008, the model of public-private partnership is more and more frequently used by public entities to realise the entrusted tasks. The public sector is also better prepared to form a partnership with private entities, as evidenced by a decreasing number of annulled proceedings because of formal defects or because of no interest in such cooperation - out of $95 \%$ in 2009 to $17 \%$ in $2015 \mathrm{r}$. A stable tendency is using the PPP framework mainly by the local governments at different levels. However, due to the limited character of financial resources, the projects that were realised, in the majority of cases did not exceed $30 \mathrm{mln}$ PLN. Another regularity is the implementation of public-private cooperation in the regions of high rate of economic growth, such as the regions of: Małopolskie, Mazowieckie, Dolnośląskie, Wielkopolskie and Śląskie. Reports and analyses of the PPP market indicate an upwards trend and an increasing interest in realising the projects within that framework. The governments, by choosing an adequate model of the partnership, acquire new facilities and realise duties that are beyond their budget possibilities. Increasingly popular public-private cooperation gives hope that projects with an increasing value will be realised, which shall make a stable change in the quality of the services rendered in Poland within the next few years, in particular in the circumstances of limited budget resources.

\section{References}

Antoniuk, J.R. (2009). Nowa regulacja partnerstwa publiczno-prywatnego. In M. Urbaniec (Ed.), Partnerstwo publiczno-prywatne jako instrument rozwoju zrównoważonego, Częstochowa: Educator. 
European Commission. (2003). Guidelines on successful public-private partnership. Retrieved 30.08.2015 from http://ec.europa.eu.

European Commission. (2004). Project Cycle Management Guidelines. Retrieved 30.08.2015 from http://ec.europa.eu.

Geddes, M. (2005). Making Public Private Partnerships Work: Building Relationships And Understanding Cultures. Aldershot: Gower Publishing.

Herbst, I., Jagusztyn-Krynicki, T., Nowosiadły, E., Kalicki, M., \& Mysiorski, B. (2015). 6 lat PPP w Polsce. Raport Fundacji Centrum PPP. Retrieved 30.08.2015 from http://www.centrum-ppp.pl.

NIK. (2015). Informacja o wynikach kontroli. Wykonywanie zadań regionalnych izb obrachunkowych $w$ zakresie przeciwdziatania zagrożeniom wynikającym z nadmiernego zadtużania się jednostek samorządu terytorialnego. Retrieved 30.08.2015 from https://www.nik.gov.pl.

Partnerstwo Publiczno-Prywatne. (2015). Rynek partnerstwa publiczno-prywatnego $i$ koncesji w Polsce w 2014 na tle stanu obowiązującego w latach 2009-2013. Retrieved 30.08.2015 from http://www.kdg.waw.pl.

Platforma Partnerstwa Publiczno-Prywatnego. (2015). Retrieved 30.08.2015 from http://bazappp.gov.pl.

Portal Funduszy Europejskich. (2015). Retrieved 30.08.2015 from https:// www.funduszeeuropejskie.2007-2013.gov.pl.

Project Finance Poland. (2015). Retrieved 30.08.2015 from http://www.projectfinance.pl.

Public-Private Partnership in Infrastructure Resource Center. (2015). Concessions, Build-Operate-Transfer (BOT) and Design-Build-Operate (DBO) Projects. Retrieved 08.08.2015 from http://pppirc.worldbank.org.

Ustawa z dnia 19 grudnia 2008 r. o partnerstwie publiczno-prywatnym [Act of 19 December 2008 on public-private partnership] (Dz.U. 2009 nr 19 poz. 100) (Poland).

Ustawa z dnia 20 grudnia 1996 r. o gospodarce komunalnej [Act of 20 December 1996 on municipal or urban engineering] (Dz.U. $1997 \mathrm{nr} 9$ poz. 43) (Poland).

Ustawa z dnia 29 sierpnia 2014 r. o zmianie ustawy — Prawo zamówień publicznych [Act of 29 August 2014 amending the act - Public Procurement] (Dz.U. 2014 poz. 1232) (Poland).

Ustawa z dnia 29 stycznia 2004 r. Prawo zamówień publicznych [Act of 29 January 2004 - Public procurement] (Dz.U. 2004 nr 19 poz. 177) (Poland).

Ustawa z dnia 8 marca 1990 r. o samorządzie gminnym [Act of 8 March 1990 on local government] (Dz.U. $1990 \mathrm{nr} 16$ poz. 95) (Poland).

Ustawa z dnia 9 stycznia 2009 r. o koncesji na roboty budowlane lub ustugi [Act of 9 January 2009 on concession for public works or services] (Dz.U. 2009 nr 19 poz. 101) (Poland).

Yescombe, E. (2008). Partnerstwo publiczno-prywatne. Zasady wdrażania i finansowania. Kraków: Wolters Kluwer Polska. 


\section{Acknowledgements}

Author contributions: author have given approval to the final version of the article. 


\section{Appendix}

\section{Chart 1.}

Number of announced projects and number of concluded agreement in the period between 2009-2014

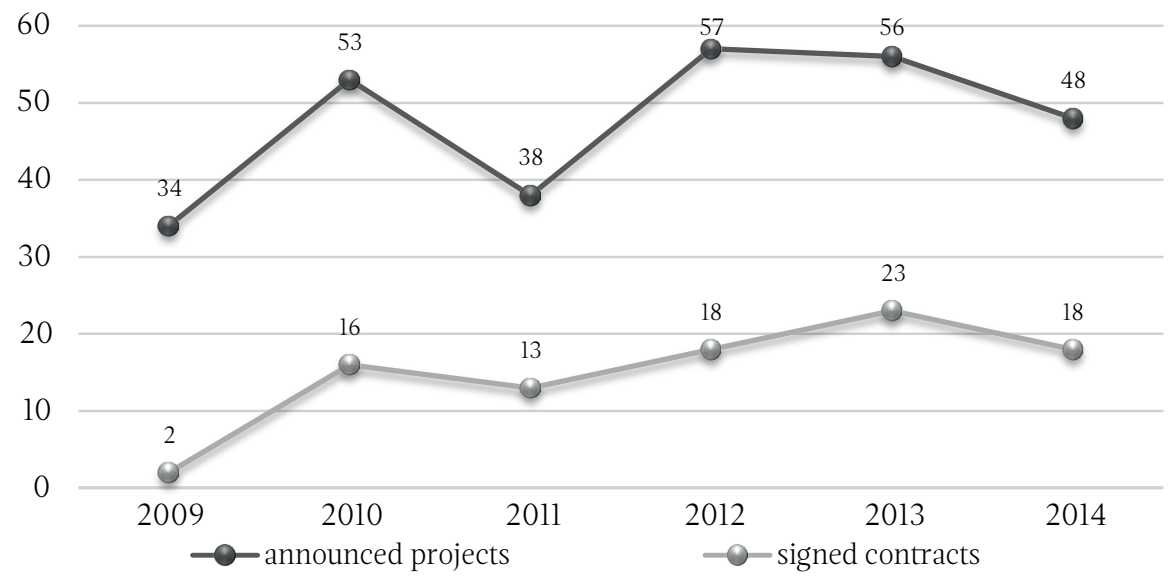

Source: Own analysis based on Platforma Partnerstwa Publiczno-Prywatnego (2015).

\section{Chart 2.}

Using the PPP framework by local governments

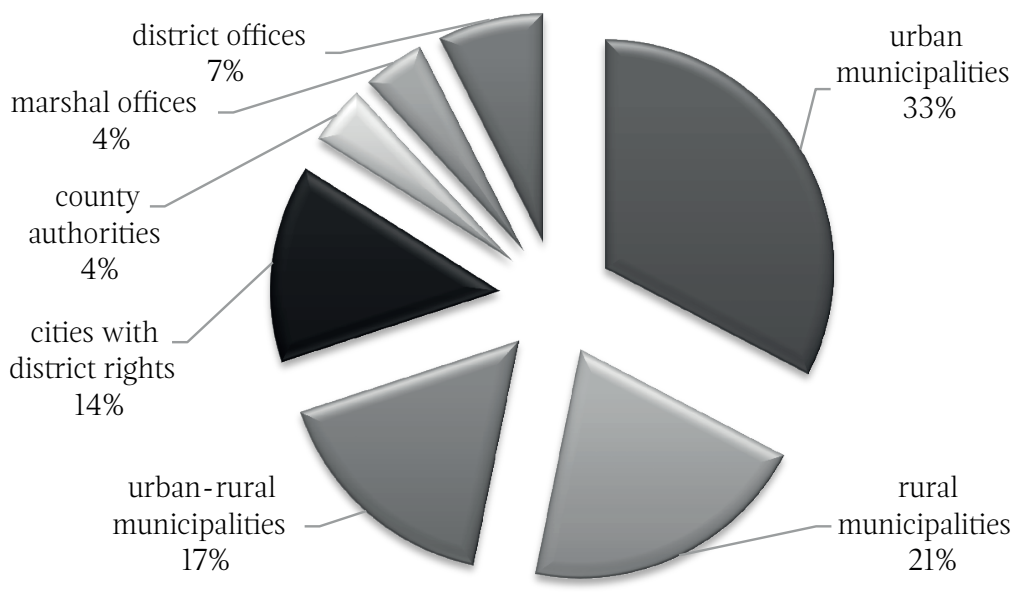

Source: Own analysis based on Platforma Partnerstwa Publiczno-Prywatnego (2015). 


\section{Chart 3.}

Using the PPP framework by entities other than local governments

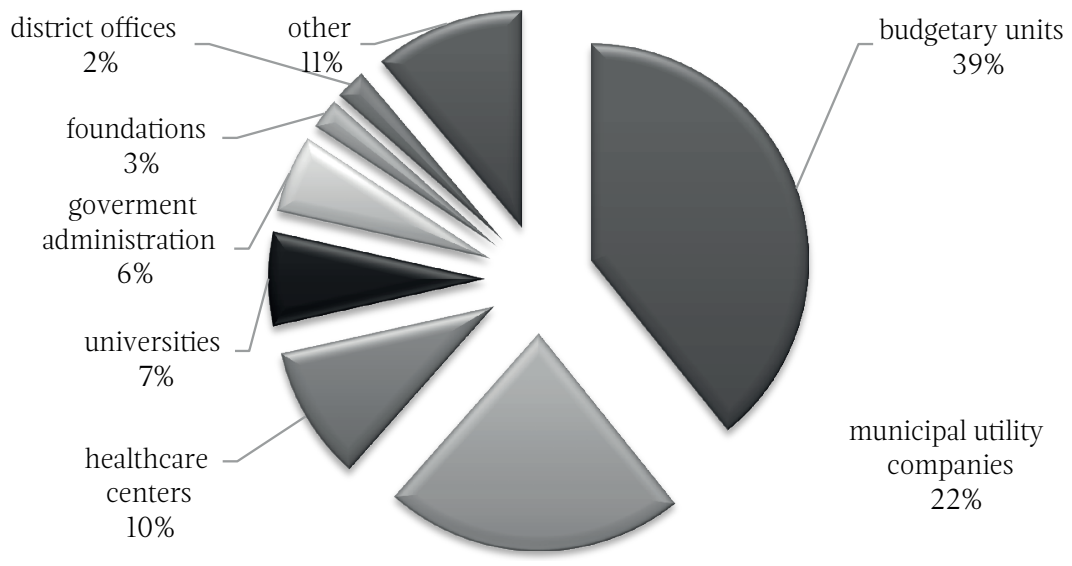

Source: Own analysis based on Platforma Partnerstwa Publiczno-Prywatnego (2015).

\section{Chart 4.}

The value of the projects realised in Poland in the period between 2009 and 2014 ( $\mathrm{mln}$ PLN)

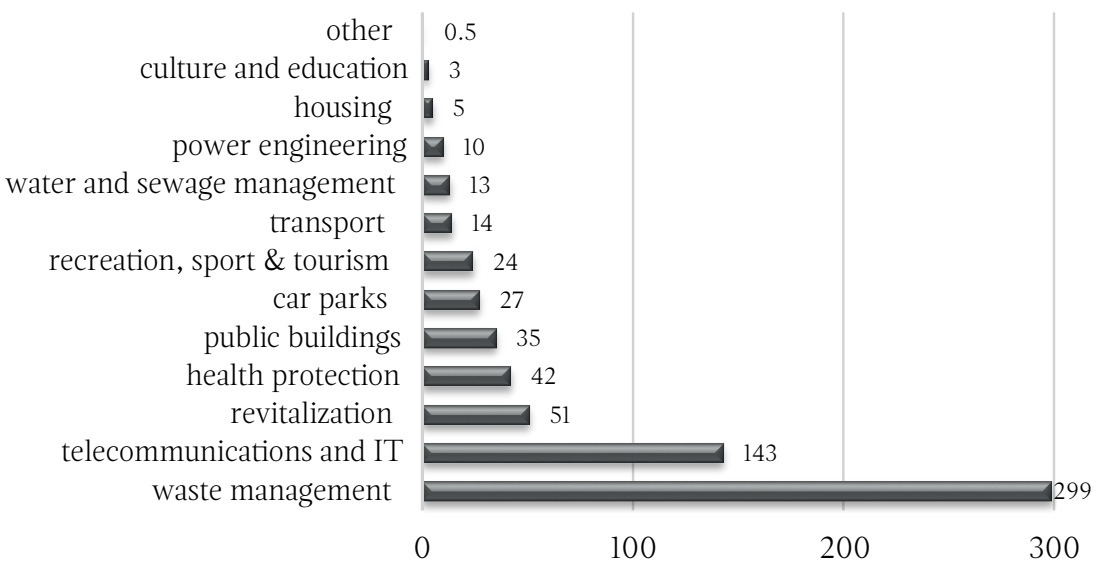

Source: Own analysis based on Herbst et al. (2015). 